\title{
Nematofauna of red piranha Pygocentrus nattereri (Kner, 1958) (Characiformes: Serrasalmidae) from Amazonia, Brazil
}

\author{
Nematofauna de piranha-vermelha Pygocentrus nattereri (Kner, 1958) (Characiformes: Serrasalmidae) da \\ Amazonia, Brasil \\ Aprígio Mota Morais ${ }^{1}$; Melissa Querido Cárdenas²* (1); José Celso de Oliveira Malta ${ }^{1}$ \\ ${ }^{1}$ Laboratório de Parasitologia de Peixes, Instituto Nacional de Pesquisas da Amazônia - INPA, Manaus, AM, Brasil \\ ${ }^{2}$ Laboratório de Helmintos Parasitos de Peixes, Instituto Oswaldo Cruz, Fundação Oswaldo Cruz - Fiocruz, Rio de Janeiro, RJ, Brasil
}

Received March 28, 2019

Accepted June 17, 2019

\begin{abstract}
Between March and October 2008, 355 specimens of Pygocentrus nattereri were collected from the lowland lakes of Central Amazonia, Brazil, to study their nematode fauna. A total of 1.116 specimens of Nematoda were collected, belonging to six species. Procamallanus (Spirocamallanus) inopinatus was the species with the highest parasite indices. Larvae of Anisakis sp. have zoonotic potential and were found parasitizing the intestine and liver of Pygocentrus nattereri. Some of these nematode species were new records for the host $P$. nattereri. The diversity of nematodes that use $P$. nattereri as a host indicates the important role of this fish species in the maintenance of these six nematode species in the lowland lakes of Central Amazonia.
\end{abstract}

Keywords: Fish parasites, Nematoda, biodiversity, Amazonas, helminths.

\section{Resumo}

Entre março e outubro de 2008, foram coletados 355 espécimes de Pygocentrus nattereri para o estudo da Nematofauna, provenientes dos lagos de várzea da Amazônia Central, Brasil. Um total de 1.116 espécimes de Nematoda foram coletados, pertencentes a seis espécies. Procamallanus (Spirocamallanus) inopinatus foi a espécie com índices parasitários mais elevados. Larvas de Anisakis sp. apresentam um potencial zoonótico, e foram encontradas parasitando o intestino e o fígado de P. nattereri. Algumas espécies de nematoides estáo sendo registradas em $P$. nattereri pela primeira vez. A diversidade de espécies de nematoides que utilizam $P$. nattereri como hospedeiro indica seu importante papel na manutenção destas cinco espécies nos lagos de várzea da Amazônia Central.

Palavras-chave: Parasitos de peixes, Nematoda, biodiversidade, Amazonas, helmintos.

\section{Introduction}

South America is undoubtedly a region where parasite biodiversity is clearly underestimated. The great ichthyological diversity of the region shows the huge dimension of the challenge for basic knowledge of helminth fauna from fish in this continent (LUQUE $\&$ POULIN, 2007). The Amazon basin is a center of diversity for most groups of Neotropical fish and it is an area of high species richness. Conservative estimates suggest there are about 3,000 fish species in this basin (ALBERT \& REIS, 2011; JUNK, 2013; FROESE \& PAULY, 2019; SANTOS \& TAVARES-DIAS, 2017).

In recent years, parasites have been recognized as an important component of global biodiversity (POULIN \& MORAND, 2004).

*Corresponding author: Melissa Querido Cárdenas. Laboratório de Helmintos Parasitos de Peixes, Instituto Oswaldo Cruz, Fundação Oswaldo Cruz - Fiocruz, Av. Brasil, 4365, CEP 21040-900, Rio de Janeiro, RJ, Brasil. e-mail melissaq@ioc.fiocruz.br
Studies using taxonomic and systematic approaches are the key to understand how biotic and abiotic factors affect species, since the effects on a population cannot be understood without knowing the species (TAKEMOTO et al., 2009).

Nematodes constitute an important group of parasites from fish. They infect freshwater, marine and brackish water fish species and sometimes cause substantial damage to the host. Most nematodes infect fish as adults, but a large proportion of them do so as larval stages, which may affect the marketing of fish. Some nematode species can accidentally infect humans (THATCHER, 2006; ABDALLAH et al., 2012).

The red piranha (Pygocentrus nattereri Kner, 1858) is a carnivorous fish found in abundance in rivers in Central and South America. It is a predator with strong jaws and sharp-edged teeth, and it reaches up to $50 \mathrm{~cm}$ in total body length. Its high abundance, wide distribution and large muscles make it viable 
for use in human nutrition in the form of broths and filleting for sashimi (BARROS et al., 2010).

To date, 13 endohelmints species have been reported in P. nattereri from Brazil: the nematodes Eustrongylides ignotus Jäegerskiold, 1909 larvae (MORAVEC, 1998), Eustrongylides sp. larvae (BARROS et al., 2010; EIRAS et al., 2010; VICENTIN et al., 2013), Contracaecum sp. larvae (PAVANELLI et al., 2004; VICENTIN et al., 2013), Procamallanus (S.) inopinatus Travassos, Artigas \& Pereira, 1928 (THATCHER, 2006; VICENTIN et al., 2013), Brevimulticaecum sp. larvae (VIEIRA et al., 2010; VICENTIN et al., 2013), Procamallanus sp. (BARROS et al., 2010), Philometra nattereri Cárdenas, Moravec, Fernandes \& Morais, 2012 (CÁRDENAS et al., 2012) and Philometridae gen. sp. (VICENTIN et al., 2013); an undetermined species of Acanthocephala (EIRAS et al., 2010) and Echinorhynchus paranensis Machado Filho, 1959 (VICENTIN et al., 2013); the cestode Proteocephalus serrasalmus Rego \& Pavanelli, 1990 (REGO \& PAVANELLI, 1990); the metacercariae of Clinostomum marginatum (Braun, 1899) and Austrodiplostomum compactum (Lutz, 1928) (MORAIS et al., 2011).

Parasite species are a significant part of food webs, have an impact on the trophic structure and may even comprise half of the host organizational diversity (MARCOGLIESE \& CONE, 1997; LAFFERTY et al., 2008; RUEHLE et al., 2017; BAIA et al., 2018). Most of the nematode parasites of fishes have a heteroxenous life cycle that includes more than one host, and fishes can act as intermediate or definitive. Considering that $P$. nattereri occupies a high position in the trophic web, this fish can harbor larvae and adults of nematodes. Parasites play fundamental roles in natural ecosystems. They can regulate host population abundance, influence the diversity and composition of communities and stabilize food webs (ALCÂNTARA \& TAVARES-DIAS, 2015; OLIVEIRA et al., 2016; FERREIRA \& TAVARES-DIAS, 2017). The knowledge of parasites communities of fishes, specially those with commercial interest, are of great importance since the data can be used in addition with other indicators to collaborate to the knowledge of migrations patterns, biology, and phylogeny. The aim of the present study was to describe the nematode fauna of $P$. nattereri from Central Amazonia, Brazil.

\section{Materials and Methods}

Collections in this study were authorized by the Brazilian Government's Chico Mendes Institute for Biodiversity and Conservation (ICMBIO, license number 44652-1). From March to October 2008, 355 specimens of $P$. nattereri were collected off six floodplain lakes located on the Solimóes River banks Baixio
(0317'27,2" S/6004'29,6"O); Preto (0321'17,1" S/60³7'28,6" O);

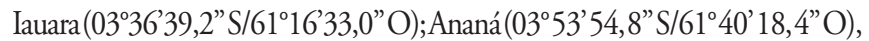

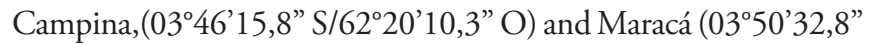
$\mathrm{S} / 62^{\circ} 3432,4^{\prime \prime} \mathrm{O}$ ), all located between the cities of Manaus and Coari in the state of Amazonas. The nematodes collected were washed in $0.65 \% \mathrm{NaCl}$ solution, fixed in hot AFA (2\% glacial acetic acid, 3\% formaldehyde and $95 \%$ ethanol $70^{\circ} \mathrm{GL}$ ) and for light microscopical examination (LM) they were cleared in phenol, according to Eiras et al. (2000). After that, they were observed using a Zeiss Axioscope 2 or Olympus BH-2 microscope equipped with a digital camera. All measurements are in millimeters, unless otherwise stated, and the range is presented followed by the mean in parentheses. Fish names follow FishBase (FROESE \& PAULY, 2019).

To describe the parasitological parameters, data related to parasite as prevalence $(\mathrm{P})$, intensity $(\mathrm{I})$, mean intensity $(\mathrm{MI})$ and range (R) were used according to Bush et al. (1997).

Specimens studied were deposited in the Helminthological Collection of "Instituto Oswaldo Cruz", Rio de Janeiro, Brazil or in the Invertebrate Collection, Nematodes, "Instituto Nacional de Pesquisas da Amazônia” (INPA), Manaus, Brazil.

\section{Results}

A total of 355 specimens of Pygocentrus nattereri measuring $15.4 \mathrm{~cm} \pm 3.5$ in standard length and weighting $230.9 \mathrm{~g} \pm 2.7$ were examined, of which were collected 1,116 nematode specimens belonging to six species. Three nematode species were represented by adult specimens: Procamallanus (Spirocamallanus) inopinatus Travassos, Artigas \& Pereira, 1928; Philometra nattereri Cárdenas, Moravec, Fernandes \& Morais, 2012 and Capillariidae gen. sp. The other three nematode species were represented by larval stages: Anisakis sp., Pseudoproleptus sp. and Brevimulticaecum sp. (Table 1).

Procamallanus (Spirocamallanus) inopinatus was the most prevalent species (100\%). Capillariidae gen. sp. was found in only one fish specimen and thus presented the lowest intensity of infection. Anisakis sp., Pseudoproleptus sp. and Capillariidae gen. sp. were reported here for the first time in P. nattereri (Table 1).

Considering that the nematode species found in the present study are already well described, only the main measurements with a brief description are presented here. The morphometric assessment on our material was in agreement with what had previously been reported.

Family Anisakidae Raillet \& Henry, 1912

Genus Anisakis Dujardin, 1945

Anisakis sp. (third-stage larvae)

Table 1. Site of infection (SI), development stage (DS), prevalence (P), intensity (I), mean intensity (MI) and range (R) of nematodes collected from Pygocentrus nattereri in Brazil.

\begin{tabular}{llcccc}
\hline \multicolumn{1}{c}{ Parasite Species } & \multicolumn{1}{c}{ SI } & DS & P (\%) & I & MI \\
\hline Anisakis sp.* & Intestine & Larvae & 8.73 & 159 & $5.13 \pm 4.28$ \\
Brevimulticaecum sp. & Intestine and Pyloric Caecum & Larvae & 3.66 & 53 & $4.08 \pm 1.82$ \\
Capillariidae gen. sp.* & Intestine & Adult & 0.56 & 2.0 & $1.00 \pm 0.41$ \\
Philometra nattereri & Oculo-orbits and Nasal Mucosa & Adult & 11.83 & 66 & $1.57 \pm 1.19$ \\
Procamallanus S.) inopinatus & Intestine and Pyloric Caecum & Adult & 100 & 938 & $2.64 \pm 2.90$ \\
Pseudoproleptus sp.* & Pyloric Caecum & Larvae & 1.40 & 57 & 11.3 \\
\hline
\end{tabular}

*New host record. 
Specimen deposited: Voucher 050 in the Invertebrate Collection, Nematodes, INPA, Manaus, Brazil.

Based on 10 larval specimens: Body 19-25 (23) in length, 0.54-0.63 (0.60) maximum width. Cuticle finely transversely striated. Excretory pore situated at the base of the anlagen lips. Ventral larval tooth present. Oesophagus 1.90-2.60 (2.10) in length. Ventriculus 0.50-0.60 (0.55) in length and 0.40-0.50 (0.48) wide. Nerve ring at 0.40-0.60 (0.50) from anterior region. Conical tail 0.15-0.19 (0.17) long, presenting a terminal mucron.

\section{Remarks}

Anisakiasis in human is commonly associated with seafood intake. The main genera involved are: Anisakis Dujardin, 1845, Pseudoterranova Mozgooi, 1951, Hysterothylacium Ward \& Magath, 1917 and Contracaecum Raillet and Henry, 1912 (HOCHBERG \& HAMER, 2010). In Brazil, Anisakis spp. larvae have been found in different marine host species of fish by many authors (PANTOJA et al., 2015a; DIAS et al., 2011; EIRAS et al., 2016). However, there are few records of Anisakis spp. larvae in fish species that inhabit freshwater and brackish water. Rodrigues et al. (2015) found Anisakis sp. larvae in Plagioscion squamosissimus (Heckel, 1840), Brachyplatystoma filamentosum (Lichtenstein, 1819) and Oxydoras niger (Valenciennes, 1821) from freshwater fish marketed in Pará, Brazil. Anisakis sp. third stage larvae were also found in P. squamosissimus, Serrasalmus altispinis Merckx, Jégu \& Santos, 2000 and Triportheus angulatus (Spix \& Agassiz, 1829) from Amazon region (FONTENELLE et al., 2016; MOREY \& MALTA, 2016; MOREIRA et al., 2017).

Larvae of the genus Contracaecum Raillet and Henry, 1912 have been reported from $P$. nattereri in different localities in Brazil (BARROS et al., 2010; BENIGNO et al., 2012; VICENTIN et al., 2013). However, the present study provides the first report of larvae of Anisakis sp. in this fish species.

In the specimens of $P$. nattereri examined here, Anisakis sp. was found in the liver and intestine. However, migration of these larvae into the musculature is not impossible. Thus, there is a risk of acquiring anisakiasis through consumption of this fish in a raw, undercooked, smoked or insufficiently salted form (KLIMPEL \& PALM, 2011).

Family Acanthocheilidae Wülker, 1929

Genus Brevimulticaecum Mozgovoy, 1951

Brevimulticaecum sp. (third-stage larvae)

Specimens deposited: Voucher 052 in the Invertebrate Collection, Nematodes, INPA, Manaus, Brazil.

Based on 11 larval specimens: Body 4.27-5.12 (4.96) length, $175-225 \mu \mathrm{m}(200 \mu \mathrm{m})$ width. Oesophagus $405-535 \mu \mathrm{m}(504 \mu \mathrm{m})$ in length. Ventriculus $25-65 \mu \mathrm{m}(52 \mu \mathrm{m})$ in length, with 4 or 5 lobes. Intestinal caecum $250-270 \mu \mathrm{m}(260 \mu \mathrm{m})$ in length. Nerve ring and excretory pore at $125-175 \mu \mathrm{m}(155 \mu \mathrm{m})$ and $187.5-190 \mu \mathrm{m}$ $(189 \mu \mathrm{m})$, respectively from anterior region. Excretory pore at $100-520 \mu \mathrm{m}(129 \mu \mathrm{m})$ from posterior region. Anus $100-520 \mu \mathrm{m}$ $(244 \mu \mathrm{m})$ from posterior end. Conical tail.

\section{Remarks}

The larval stages of Brevimulticaecum spp. have been reported parasitizing fish, reptiles and amphibians in some geographical regions (see VIEIRA et al., 2010). In Brazil, Brevimulticaecum spp. larvae have been reported from the following different freshwater fishes: Leporinus lacustris Amaral Campos, 1945, Leporinus friderici (Bloch, 1794) and Potamotrygon falkneri Castex \& Maciel, 1963 (GUIDELLI et al., 2006; LACERDA et al., 2008, 2009); Leporinus macrocephalus Garavello \& Britski, 1988 (MARTINS et al., 2017); Gymnotus inaequilabiatus (Valenciennes, 1839), Hemisorubim platyrhynchos (Valenciennes, 1840), Hoplias malabaricus (Bloch, 1794), Myleus levis (Eigenmann \& McAtee, 1907), Pseudoplatystoma corruscans (Spix \& Agassiz, 1829), Serrasalmus marginatus (Valenciennes, 1837) and Sorubim lima (Bloch \& Schneider, 1801) (VIEIRA et al., 2010; VICENTIN et al., 2011; DEZFULI et al., 2016); P. nattereri (VIEIRA et al., 2010; VICENTIN et al., 2013); and Astyanax fasciatus (Cuvier, 1819) (VIEIRA-MENEZES et al., 2017). Vicentin et al. (2013) observed higher prevalence (19.08\%) and mean intensity (117.24 \pm 125.91$)$ of Brevimulticaecum sp. larvae than what was observed in the present study $(\mathrm{P}=3.66 \% ; \mathrm{MI}=4.08 \pm 1.82)($ Table 1$)$.

Superfamily Trichinelloidea Ward, 1907 (1879)

Family Capilariidae Railliet, 1915

Capillariidae gen. sp.

Specimens deposited: Voucher 053 in the Invertebrate Collection, Nematodes, INPA, Manaus, Brazil.

Thin, thread-like nematodes. Cuticle bearing two longitudinal bacillary bands. Eggs barrel-shaped. Vulva near distal end of oesophagus with elevated lips.

\section{Remarks}

In Brazil, nematodes belonging to the family Capillariidae have been reported from different host fishes from different localities (LUQUE et al., 2011). In the Amazon region, only two species have been reported: Paracapillaria (Paracapillaria) piscicola (Travassos, Artigas \& Pereira, 1928) parasitizing Acestrorhamphus sp. (THATCHER, 2006); and Capillostrongyloides arapaimae Santos, Moravec \& Venturieri, 2008, parasitizing Arapaima gigas (Schinz, 1822) (SANTOS et al., 2008).

In the present study, only two specimens (females) in a poor condition were found, making it difficult to establish the genus and species accurately. However, this record of the family Capillariidae in $P$. nattereri for the first time contributes towards biodiversity knowledge.

Family Philometridae Baylis \& Daubney, 1926

Genus Philometra Costa, 1845

Philometra nattereri Cárdenas, Moravec, Fernandes \& Morais 2012

Specimens deposited: Paratypes (35778-35782) in the Helminthological Collection,

Instituto Oswaldo Cruz (CHIOC), Rio de Janeiro, Brazil; other paratypes (046 and 047) in the Invertebrate Collection, Nematodes, INPA, Manaus, Brazil.

Measurements of this species were presented in the original description (CÁRDENAS et al., 2012). 


\section{Remarks}

Only three valid species of Philometra Costa, 1845 have so far been reported from freshwater fish in South America, all described solely from available females: Philometra baylisi Vaz \& Pereira, 1934, from the abdominal cavity of Pimelodus blochii Valenciennes, 1840 in Brazil (VAZ \& PEREIRA, 1934); Philometra nattereri Cárdenas, Moravec, Fernandes \& Morais, 2012, from the ocular orbits and nasal mucosa of $P$. nattereri in the Brazilian Amazon region (CÁRDENAS et al., 2012); and Philometra mirabilis Moravec \& Diggles, 2015 from the gonads of Cichla mirianae Kullander \& Ferreira, 2006 (Cichliformes, Cichlidae) in the Brazilian Amazon region (MORAVEC \& DIGGLES, 2015). However, the allocation of $P$. baylisi to Philometra is uncertain (MORAVEC, 2006). Vicentin et al. (2013) reported finding one specimen of Philometra sp. in the body cavity of $P$. nattereri but, according to these authors, this specimen differed in some aspects from $P$. nattereri.

Although only three valid species of Philometra from freshwater fishes in Brazil have been described, it can be expected that new species of this group will be discovered and described.

Family Camallanidae Railliet \& Henry, 1915

Genus Procamallanus Baylis, 1923

Procamallanus (Spirocamallanus) inopinatus Travassos, Artigas \& Pereira, 1928

Specimens deposited: Voucher 048 and 049 in the Invertebrate Collection, Nematodes, INPA, Manaus, Brazil.

Adults are characterized by their orange-brown, undivided, thick-walled buccal capsule in both sexes.

Males (based on 10 specimens): Body 4.30-6.00 (5.20) long by $0.22-0.36(0.27)$ wide. Buccal capsule with 0.06- $0.14(0.12)$ in length by 0.05-0.12 (0.09) maximum width, with 18-19 (19) ridges. Muscular and glandular regions of the esophagus are 0.27-0.37 (0.32) and 0.47-0.62 (0.52) respectively. Nerve ring at 0.02-0.13 (0.07) from the anterior extremity. Posterior end of body provided with 10 pairs of caudal papillae (4 pairs of precloacal papillae and 6 pairs of postcloacal papillae). Two equal spicules with 0.14-0.16 (0.15) long.

Females (based on 10 specimens): Body 12.00-30.25 (22.70) in length by 0.52-0.96 (0.75) in width. Buccal capsule with $0.12-0.17(0.15)$ in length by $0.15-0.18(0.16)$ wide, with 20-22 (19) ridges. Muscular and glandular regions of the esophagus with 0.55-0.63 (0.52) and 0.80-0.99 (0.90) respectively. Nerve ring at $0.02-0.10(0.05)$ from the anterior extremity. Conical tail.

\section{Remarks}

Procamallanus (Spirocamallanus) inopinatus has been reported from different host fishes in different localities in Brazil (LUQUE et al., 2011), including the Amazon region (THATCHER, 2006; ANDRADE \& MALTA, 2006; GONÇALVES et al., 2016; SANTOS \& TAVARES-DIAS, 2017). This nematode species was reported parasitizing $P$. nattereri in the state of Mato Grosso do Sul, Brazil, by Pinto \& Noronha (1976) and Vicentin et al. (2013). Barros et al. (2010) reported finding Procamallanus spp. in $P$. nattereri caught in the Cuiabá river, state of Mato Grosso,
Brazil, and Benigno et al. (2012) reported finding Procamallanus sp. in Arari lake, Marajó island, state of Pará, Brazil.

Family Cystidicolidae Skrjabin, 1946

Genus Pseudoproleptus Khera, 1956

Pseudoproleptus sp. (third-stage larvae)

Specimens deposited: Voucher 051 in the Invertebrate Collection, Nematodes, INPA, Manaus, Brazil.

Based on 10 larval specimens: Body filiform, 12.25 - 24.70 (20.76) long and 149-150 (150) wide. Anterior end of body with helmet-like cuticular structure with $32-35 \mu \mathrm{m}(33 \mu \mathrm{m})$ in length from anterior end. Vestibule including prostom $177-187 \mu \mathrm{m}(181 \mu \mathrm{m})$ in length. Length of muscular esophagus 0.690-0.695 (0.692); length of glandular esophagus 2.66-4.18 (3.33). Nerve ring and excretory pore $250-275 \mu \mathrm{m}(262 \mu \mathrm{m})$ and $507-540 \mu \mathrm{m}(522 \mu \mathrm{m})$, respectively, from anterior extremity. Anus 100 to $145 \mu \mathrm{m}(122 \mu \mathrm{m})$ from posterior extremity.

\section{Remarks}

In Brazil, third-stage larvae of Pseudoproleptus sp. were reported for the first time in the prawn Macrobrachium amazonicum (Heller, 1862) from Mexiana island (Amazon river delta), state of Pará (MORAVEC \& SANTOS, 2009). Subsequently, the third-stage larvae of this nematode were reported in the Satanoperca jurupari Heckel, 1840 and Ageneiosus ucayalensis Castelnau, 1855 (MELO et al., 2011), Aequidens tetramerus (Heckel, 1840) (TAVARES-DIAS et al., 2014), Mesonauta acora Castelnau, 1855 (PANTOJA et al., 2015b), for second time from a fish in the Neotropical region. We agree with Melo et al. (2011) that this fish should be considered a paratenic host for this nematode species.

\section{Discussion}

The parasite community structure of fish is mostly influenced by host physiology, ecology and phylogeny (HOSHINO et al., 2016). Differences in species richness and diversity of parasites may also be a result of the host's individual responses to parasitism and transmission rates, among other factors (TAKEMOTO et al., 2009; TAVARES-DIAS et al., 2013; SHAH et al., 2014). Therefore, biotic factors such as the host immunity may have a differential effect on a fish-parasite environment system (NEVES et al., 2016).

The trophical level of $P$. nattereri, together with the large population of this species in lowland environments, shows that it is a species that can act as an intermediate, paratenic or definitive host for several species of nematode, thereby facilitating completion of their life cycles. This assertion is corroborated by the presence of parasite species, both in adult form (such as Procamallanus (Spirocamallanus) inopinatus) and in larval form (such as Pseudoproleptus sp., Brevimulticaecum sp. and Anisakis sp.) in the present study.

Pygocentrus nattereri is a very abundant species in the Amazon region and is widely used in feeding the regional population. Thus, it is considered to be a commercial species (SANTOS et al., 2006). With increasing consumption of this species and a lack of sanitary inspection to detect pathogens, there is a risk of increasing 
incidence of zoonoses, especially because of the popularization of its use in prepared dishes based on raw fish (BARROS et al., 2007; MORAIS et al., 2011). The presence of Anisakis sp. in P. nattereri in the present study demonstrates that the use of raw fish or undercooked fish in food presents an eminent risk of zoonoses.

The diversity of fish species in Brazil, including both freshwater and marine species, is one of the richest in the world, especially concerning freshwater fish. Fish diversity is not in itself a risk factor for fish-borne nematode infections, and probably not all the species serve as hosts. However, the great number of fish species infected, especially in the case of economically important species, increases the risk that humans will ingest fish infected with nematodes (EIRAS et al., 2016).

Previous studies showed that infrapopulations of metazoan endoparasites of $P$. nattereri presented low parasite indexes, such as prevalence and abundance, except in the case of $P$. (S.) inopinatus (CARVALHO et al., 2004; BARROS et al., 2010; VICENTIN et al., 2013). In the present study, similar parasite indexes were found in P. nattereri from the Solimóes river. The present findings can be explained by similarities in the environment, in which all hosts were collected from natural rivers. The same nematode species, $P$. (S.) inopinatus, showed the highest values, demonstrating that specimens of $P$. nattereri from different rivers had the same opportunities to find the intermediate hosts with infective stages.

Fish of wild populations have a more diversified diet than those in manmade lakes and reservoirs, which can positively affect the composition of endoparasites because the diet can include numerous animals that act as intermediate and/or paratenic hosts (PEREIRA et al., 2018). In the present study, Capillariidae gen. sp., the third-stage larvae of Anisakis sp., Pseudoproleptus sp. and Brevimulticaecum sp. are reported for the first time in $P$. nattereri, thus contributing to biodiversity knowledge.

\section{Acknowledgements}

The authors are grateful to FINEP, PETROBRAS, PIATAM project (Projeto Inteligência Socioambiental Estratégica da Indústria do Petróleo na Amazônia), FAPEAM (Fundação de Amparo à Pesquisa do Estado do Amazonas), INPA/MCT, FAPERJ (Fundação Carlos Chagas Filho de Amparo à Pesquisa do Estado do Rio de Janeiro) and CNPq (Conselho Nacional de Desenvolvimento Científico e Tecnológico). To the anonymous reviewers for the valuable suggestions that improved this manuscript.

\section{References}

Abdallah VD, Azevedo RK, Carvalho ED, Silva RJ. New hosts and distribution records for nematode parasites of freshwater fishes from São Paulo State, Brazil. Neotrop Helminthol 2012; 6(1): 43-57.

Albert JS, Reis RE. Historical biogeography of Neotropical freshwater fishes. Berkeley: University of California Press; 2011. http://dx.doi.org/10.1525/ california/9780520268685.001.0001.

Alcântara NM, Tavares-Dias M. Structure of the parasites communities in two Erythrinidae fish from Amazon River system (Brazil). Rev Bras Parasitol Vet 2015; 24(2): 183-190. http://dx.doi.org/10.1590/S198429612015039. PMid:26083690.
Andrade SMS, Malta JCO. Parasite fauna monitoring of matrinxã Brycon amazonicus (Spix \& Agassiz, 1829) raised in an intensive husbandry system in a stream channel in the state of Amazonas, Brazil. Braz J Biol 2006; 66(4): 1123-1132. http://dx.doi.org/10.1590/S1519-69842006000600020. PMid:17299949.

Baia RRJ, Florentino AC, Silva LMA, Tavares-Dias M. Patterns of the parasite communities in a fish assemblage of a river in the Brazilian Amazon region. Acta Parasitol 2018; 63(2): 304-316. http://dx.doi. org/10.1515/ap-2018-0035. PMid:29654690.

Barros LA, Mateus LAF, Braum DT, Bonaldo J. Aspectos ecológicos de endoparasitos de piranha vermelha (Pygocentrus nattereri, Kner,1860) proveniente do rio Cuiabá. Arq Bras Med Vet Zootec 2010; 62(1): 228231. http://dx.doi.org/10.1590/S0102-09352010000100033.

Barros LA, Moraes-Filho J, Oliveira RL. Larvas de nematóides de importância zoonótica encontradas em traíras (Hoplias malabaricus Bloch, 1794) no município de Santo Antônio do Leverger, MT. Arq Bras Med Vet Zootec 2007; 59(2): 533-535. http://dx.doi.org/10.1590/ S0102-09352007000200042.

Benigno RNM, Clemente SCS, Matos ER, Pinto RM, Gomes DC, Knoff M. Nematodes in Hoplerytrinus unitaeniatus, Hoplias malabaricus and Pygocentrus nattereri (pisces characiformes) in Marajó Island, Brazil. Rev Bras Parasitol Vet 2012; 21(2): 165-170. http://dx.doi.org/10.1590/ S1984-29612012000200018. PMid:22832760.

Bush AO, Lafferty KD, Lotz MJ, Shostak AW. Parasitology meets ecology on its own terms: Margolis et al. revisited. J Parasitol 1997; 83(4): 575583. http://dx.doi.org/10.2307/3284227. PMid:9267395.

Cárdenas MQ, Moravec F, Fernandes BMM, Morais AM. A new species of Philometra Costa, 1845 (Nematoda: Philometridae) from the freshwater fish (red piranha) Pygocentrus nattereri Kner (Characidae) in Amazonia, Brazil. Syst Parasitol 2012; 83(2): 137-144. http://dx.doi.org/10.1007/ s11230-012-9377-4. PMid:22983801.

Carvalho LN, Arruda R, Del-Claro K. Host-parasite interactions between the piranha Pygocentrus nattereri (Characiformes: Characidae) and isopods and branchiurans (Crustacea) in the Rio Araguaia basin, Brazil. Neotrop Ichthyol 2004; 2(2): 93-98. http://dx.doi.org/10.1590/ S1679-62252004000200006.

Dezfuli BS, Fernandes CE, Galindo GM, Castaldelli G, Manera M, Pasquale JA, et al. Nematode infection in liver of the fish Gymnotus inaequilabiatus (Gymnotiformes: Gymnotidae) from the Pantanal Region in Brazil: pathobiology and inflammatory response. Parasit Vectors 2016; 9(1): 473. http://dx.doi.org/10.1186/s13071-016-1772-2. PMid:27576434.

Dias FJ, São Clemente SC, Pinto RM, Knoff M. Anisakidae nematodes and Trypanorhyncha cestodes of hygienic importance infecting the king mackerel Scomberomorus cavalla (Osteichthyes: Scombridae) in Brazil. Vet Parasitol 2011; 175(3-4): 351-355. http://dx.doi.org/10.1016/j. vetpar.2010.10.014. PMid:21115292.

Eiras JC, Pavanelli GC, Takemoto RM, Yamaguchi MU, Karkling LC, Nawa Y. Potential risk of fish-borne nematode infections in humans in Brazil - Current status based on a literature review. Food Water Parasitol 2016; 5: 1-6. http://dx.doi.org/10.1016/j.fawpar.2016.08.002.

Eiras JC, Takemoto RM, Pavanelli GC. Diversidade dos parasitas de peixes de água doce do Brasil. Maringá: Clichetec; 2010.

Eiras JC, Takemoto RM, Pavanelli GC. Métodos de estudo e técnicas laboratoriais em parasitologia de peixes. Maringá: EDUEM; 2000.

Ferreira DO, Tavares-Dias M. Ectoparasites and endoparasites community of Ageneiosus ucayalensis (Siluriformes: Auchenipteridae), catfish from 
Amazon River system in northern Brazil. J Parasit Dis 2017; 41(3): 639646. http://dx.doi.org/10.1007/s12639-016-0857-3. PMid:28848252.

Fontenelle G, Knoff M, Felizardo NN, Torres EJL, Matos ER, Gomes DC, et al. Anisakid larva parasitizing Plagioscion squamosissimus in Marajó Bay and Tapajós River, state of Pará, Brazil. Rev Bras Parasitol Vet 2016; 25(4): 492-496. http://dx.doi.org/10.1590/s1984-29612016034. PMid:28001171.

Froese R, Pauly D, editors. FishBase [online]. Mumbai: FishBase Team; 2019 [cited 2019 June 18]. Available from: www.fishbase.org

Gonçalves RA, Oliveira MS, Neves LR, Tavares-Dias M. Seasonal pattern in parasite infracommunities of Hoplerythrinus unitaeniatus and Hoplias malabaricus (Actinopterygii: Erythrinidae) from the Brazilian Amazon. Acta Parasitol2016; 61(1): 119-129. http://dx.doi.org/10.1515/ap-20160016. PMid:26751882.

Guidelli G, Tavechio WLG, Takemoto RM, Pavanelli GC. Fauna parasitária de Leporinus lacustris e Leporinus friderici (Characiformes, Anostomidae) da planície de inundação do alto rio Paraná, Brasil. Acta Sci Biol Sci 2006; 28(3): 281-290. http://dx.doi.org/10.4025/actascibiolsci.v28i3.228.

Hochberg NS, Hamer DH. Anisakidosis: perils of the deep. Clin Infect Dis 2010; 51(7): 806-812. http://dx.doi.org/10.1086/656238. PMid:20804423.

Hoshino MD, Neves LR, Tavares-Dias M. Parasite communities of the predatory fish, Acestrorhynchus falcatus and Acestrorhynchus falcirostris, living in sympatry in Brazilian Amazon. Rev Bras Parasitol Vet 2016; 25(2): $207-$ 216. http://dx.doi.org/10.1590/S1984-29612016038. PMid:27334822.

Junk WJ. Current state of knowledge regarding South America wetlands and their future under global climate change. Aquat Sci 2013; 75(1): 113-131. http://dx.doi.org/10.1007/s00027-012-0253-8.

Klimpel S, Palm HW. Anisakid nematode (Ascaridoidea) life cycles and distribution: increasing zoonotic potential in the time of climate change? In: Mehlhorn H. Progress in parasitology. Berlin: Springer Berlin Heidelberg; 2011. p. 201-222. http://dx.doi.org/10.1007/978-3-642-21396-0_11.

Lacerda ACF, Takemoto RM, Pavanelli GC. Digenea, Nematoda, Cestoda, and Acanthocephala, parasite in Potamotrygonidae (Chondrichthyes) from the upper Paraná River floodplain, states of Paraná and Mato Grosso do Sul, Brazil. Check List 2008; 4(2): 115-122. http://dx.doi. org/10.15560/4.2.115.

Lacerda ACF, Takemoto RM, Pavanelli GC. Ecology of endoparasites of the fluvial stingray Potamotrygon falkneri (Chondrichthyes: Potamotrygonidae) from the upper Paraná River floodplain, Brazil. Braz J Biol 2009; 69(2): 297-303. http://dx.doi.org/10.1590/S1519-69842009000200009. PMid:19675930.

Lafferty KD, Allesina S, Arim M, Briggs CJ, De Leo G, Dobson AP, et al. Parasites in food webs: the ultimate missing links. Ecol Lett 2008; 11(6): 533-546. http://dx.doi.org/10.1111/j.1461-0248.2008.01174.x. PMid:18462196.

Luque JL, Aguiar JC, Vieira FM, Gibson DI, Santos CP. Checklist of Nematoda associated with the fishes of Brazil. Zootaxa 2011; 3082(1): 1-88. http://dx.doi.org/10.11646/zootaxa.3082.1.1.

Luque JL, Poulin R. Metazoan parasite species richness in Neotropical fishes: hotspots and the geography of biodiversity. Parasitology 2007; 134(6): 865-878. http://dx.doi.org/10.1017/S0031182007002272. PMid:17291392.

Marcogliese DJ, Cone DK. Food webs: a plea for parasites. Trends Ecol Evol 1997; 12(8): 320-325. http://dx.doi.org/10.1016/S01695347(97)01080-X. PMid:21238094.
Martins WMO, Justo MCN, Cárdenas MQ, Cohen SC. Metazoan parasite communities of Leporinus macrocephalus (Characiformes: Anostomidae) in cultivation systems in the western Amazon, Brazil. Acta Amazon 2017; 47(4): 301-310. http://dx.doi.org/10.1590/1809-4392201701243.

Melo MFC, Giese EG, Santos JN, Santos CP. First record of larval Pseudoproleptus sp. (Nematoda: Cystidicolidae) in fish host. Acta Trop 2011; 117(3): 212-215. http://dx.doi.org/10.1016/j.actatropica.2010.12.011. PMid:21187054.

Morais AM, Varella AMB, Fernandes BMM, Malta JCO. Clinostomum marginatum (Braun, 1899) and Austrodiplostomum compactum (Lutz, 1928) metacercariae with zoonotic potential on Pygocentrus nattereri (Kner, 1858) (Characiformes:Serrasalmidae) from Central Amazon, Brazil. Neotrop Helminthol 2011; 5(1): 8-15.

Moravec F, Diggles B. Philometra mirabilis sp. n. (Nematoda: Philometridae), a new gonad-infecting parasite from the freshwater fish Cichla mirianae (Cichlidae) in Brazilian Amazon. Parasitol Res 2015; 114(5): 1929-1932. http://dx.doi.org/10.1007/s00436-015-4381-7. PMid:25855348.

Moravec F, Santos CP. Larval Pseudoproleptus sp. (Nematoda: Cystidicolidae) found in the Amazon river prawn Macrobrachium amazonicum (Decapoda: Palaemonidae) in Brazil. J Parasitol 2009; 95(3): 634-638. http://dx.doi. org/10.1645/GE-1887.1. PMid:19014207.

Moravec F. Nematodes of freshwater fishes of the neotropical region. Prague: Institute of Parasitology, Academy of Sciences of the Czech Republic; 1998.

Moravec F. Dracunculoid and anguillicoloid nematodes parasitic in vertebrates. Prague: Academia; 2006.

Moreira AC, Oliveira TTS, Morey GAM, Malta JCO. Metazoários parasitas de Triportheus angulatus (Spix \& Agassiz, 1829) do Lago Catalão, Rio Solimốes, Amazonas, Brasil. Folia Amaz 2017; 26(1): 9-16. http:// dx.doi.org/10.24841/fa.v26i1.415.

Morey GAM, Malta JCO. Parasites with zoonotic potential in Serrasalmus altispinis Merckx, Jegue \& Santos, 2000 (Characiformes: Serrasalmidae) from floodplain lakes in the Amazon, Brazil. Neotrop Helminthol 2016; 10(2): 249-258.

Neves LR, Braga EC, Tavares-Dias M. Diversity of parasites in Curimata incompta (Curimatidae), a host from Amazon river system in Brazil. J Parasit Dis 2016; 40(4): 1296-1300. http://dx.doi.org/10.1007/s12639015-0674-0. PMid:27876934.

Oliveira MSB, Gonçalves RA, Tavares-Dias M. Community of parasites in Triportheus curtus and Triportheus angulatus (Characidae) from a tributary of the Amazon River system (Brazil). Stud Neotrop Fauna Environ 2016; 51(1): 29-36. http://dx.doi.org/10.1080/01650521.2016.1150095.

Pantoja CS, Borges JN, Santos CP, Luque JL. Molecular and morphological characterization of Anisakid Nematode larvae from the sandperches Pseudopercis numida and Pinguipes brasilianus (Perciformes: Pinguipedidae) off Brazil. J Parasitol 2015a; 101(4): 492-499. http://dx.doi.org/10.1645/14625.1. PMid:25885554.

Pantoja WMF, Flores LV, Tavares-Dias M. Parasites component community in wild population of Pterophyllum scalare Schultze, 1823 and Mesonauta acora Castelnau, 1855, cichlids from the Brazilian Amazon. J Appl Ichthyology 2015b; 31(6): 1043-1048. http://dx.doi.org/10.1111/jai.12903.

Pavanelli GC, Machado MH, Takemoto RM, Guidelli GM, Lizama MAP. Helminth fauna of fishes: diversity and ecological aspects. In: Thomaz SM, Agostinho AA, Hahn NS. The Upper Paraná River and its floodplain: physical aspects, ecology and conservation. Netherlands: Backhuys Publishers; 2004. p. 309-329. 
Pereira ES, Mauad JRC, Takemoto RM, Lima-Junior SE. Fish parasite diversity in the Amambai river, State Mato Grosso do Sul, Brazil. Acta Sci Biol Sci 2018; 40(1): e36330. http://dx.doi.org/10.4025/actascibiolsci. v40i1.36330.

Pinto RM, Noronha D. Procamallanus brasileiros (Nematoda, Camallanoidea): consideraçôes finais, com chave para determinação das espécies. Mem Inst Oswaldo Cruz 1976; 74(3-4): 323-339. http://dx.doi.org/10.1590/ S0074-02761976000300011.

Poulin R, Morand S. Parasite biodiversity. Washington: Smithsonian Institution Press; 2004.

Rego AA, Pavanelli GC. Novas espécies de cestóides proteocefalídeos: parasitas de peixes não Siluriformes. Rev Bras Biol 1990; 50(1): 91-101.

Rodrigues MV, Pantoja JCF, Guimarães CDO, Benigno RNM, Palha MDC, Biondi GF. Prevalence for nematodes of hygiene-sanitary importance in fish from Colares Island and Vigia, Pará, Brasil. R Bras Ci Vet 2015; 22(2): 24-128. http://dx.doi.org/10.4322/rbcv.2015.364.

Ruehle BP, Herrmann KK, Higgins CL. Helminth parasite assemblages in two cyprinids with different life history strategies. Aquat Ecol 2017; 51(2): 247-256. http://dx.doi.org/10.1007/s10452-017-9614-7.

Santos CP, Moravec FE, Venturieri R. Capillostrongyloides arapaimae sp. n. (Nematoda: Capillariidae), a new intestinal parasite of the arapaima Arapaima gigas from the Brazilian Amazon. Mem Inst Oswaldo Cruz 2008; 103(4): 392-395. http://dx.doi.org/10.1590/S0074-02762008000400013. PMid:18660995.

Santos GM, Efrem JGF, Zuanom JAS. Peixes comerciais de Manaus. Manaus: IBAMA/AM, ProVárzea; 2006.

Santos PHN, Tavares-Dias M. First study on communities of parasites in Triportheus rotundatus, a Characidae fish from the Amazon River system (Brazil). Rev Bras Parasitol Vet 2017; 26(1): 28-33. http://dx.doi. org/10.1590/s1984-29612016078. PMid:27925070.

Shah HB, Yousuf AR, Chrishti MZ, Shahnaz S, Ahmad F. Trophic status and helminth infracommunities of fish populations in Kashmir Himalayan lakes. J Helminthol 2014; 88(3): 264-271. http://dx.doi.org/10.1017/ S0022149X13000114. PMid:23510501.
Takemoto RM, Pavanelli GC, Lizama MAP, Lacerda ACF, Yamada FH, Moreira LHA, et al. Diversity of parasites of fish from the Upper Paraná River floodplain, Brazil. Braz J Biol 2009;69(2 Suppl. 2): 691-705. http:// dx.doi.org/10.1590/S1519-69842009000300023. PMid:19738975.

Tavares-Dias M, Neves LR, Pinheiro DA, Oliveira MSB, Marinho RGB. Parasites in Curimata cyprinoides (Characiformes: Curimatidae) from eastern Amazon, Brazil. Acta Sci Biol Sci 2013; 35(4): 595-601. http:// dx.doi.org/10.4025/actascibiolsci.v35i4.19649.

Tavares-Dias M, Oliveira MS, Gonçalves RA, Silva LM. Ecology and seasonal variation of parasites in wild Aequidens tetramerus, a Cichlidae from the Amazon. Acta Parasitol 2014; 59(1): 158-164. http://dx.doi. org/10.2478/s11686-014-0225-3. PMid:24570063.

Thatcher VE. Amazon fish parasites. 2nd ed. Sofia: Pensoft Publishers; 2006.

Vaz Z, Pereira C. Contribuição ao conhecimento dos nematóides de peixes fluviais do Brasil. Arq Inst Biol (Sao Paulo) 1934; 5: 87-103.

Vicentin W, Vieira KRI, Costa FES, Takemoto RM, Tavares LER, Paiva F. Metazoan endoparasites of Serrasalmus marginatus (Characiformes: Serrasalminae) in the Negro River, Pantanal, Brazil. Rev Bras Parasitol Vet 2011; 20(1): 61-63. http://dx.doi.org/10.1590/S1984-29612011000100012. PMid:21439234.

Vicentin W, Vieira KRI, Tavares LER, Costa FES, Takemoto RM, Paiva F Metazoan endoparasites of Pygocentrus nattereri (Characiformes: Serrasalminae) in the Negro River, Pantanal, Brazil. Rev Bras Parasitol Vet 2013; 22(3): 331-338. http://dx.doi.org/10.1590/S1984-29612013000300003. PMid:24142162.

Vieira KRI, Vicentin W, Paiva F, Pozo CF, Borges FA, Adriano EA, et al. Brevimulticaecum sp. (Nematoda: Heterocheilidae) larvae parasitic in freshwater fish in the Pantanal wetland, Brazil. Vet Parasitol 2010; 172(3-4): 350-354. http://dx.doi.org/10.1016/j.vetpar.2010.05.003. PMid:20684864.

Vieira-Menezes FG, Costa DPC, Brasil-Sato MC. Nematodes of Astyanax fasciatus (Actinopterygii: Characidae) and their parasitic indices in the São Francisco river, Brazil. Rev Bras Parasitol Vet 2017; 26(1): 10-16. http:// dx.doi.org/10.1590/s1984-29612016074. PMid:28177039. 